\title{
Robust asset allocation in incomplete markets
}

Citation for published version (APA):

Shen, S. (2015). Robust asset allocation in incomplete markets. [Doctoral Thesis, Maastricht University]. Datawyse / Universitaire Pers Maastricht. https://doi.org/10.26481/dis.20150622ss

Document status and date:

Published: 01/01/2015

DOI:

10.26481/dis.20150622ss

Document Version:

Publisher's PDF, also known as Version of record

\section{Please check the document version of this publication:}

- A submitted manuscript is the version of the article upon submission and before peer-review. There can be important differences between the submitted version and the official published version of record.

People interested in the research are advised to contact the author for the final version of the publication, or visit the DOI to the publisher's website.

- The final author version and the galley proof are versions of the publication after peer review.

- The final published version features the final layout of the paper including the volume, issue and page numbers.

Link to publication

\footnotetext{
General rights rights.

- You may freely distribute the URL identifying the publication in the public portal. please follow below link for the End User Agreement:

www.umlib.nl/taverne-license

Take down policy

If you believe that this document breaches copyright please contact us at:

repository@maastrichtuniversity.nl

providing details and we will investigate your claim.
}

Copyright and moral rights for the publications made accessible in the public portal are retained by the authors and/or other copyright owners and it is a condition of accessing publications that users recognise and abide by the legal requirements associated with these

- Users may download and print one copy of any publication from the public portal for the purpose of private study or research.

- You may not further distribute the material or use it for any profit-making activity or commercial gain

If the publication is distributed under the terms of Article $25 \mathrm{fa}$ of the Dutch Copyright Act, indicated by the "Taverne" license above, 


\section{Nederlanse Samenvatting}

Mijn onderzoek is geïnspireerd door het werk van Hansen and Sargent (2007) over het nemen van robuste economische beslissingen met een onzeker model. In dat werk vermoeden zij dat het langzame respons van economische beslissers tijdens de recente recessie of voor het maken van fiscaal en monetair beleid verklaard kan worden door de onzekerheid waarin zij verkeren. Echer, het werk door Hansen en Sargent is gelimiteerd tot macro-economische perspectieven en de parameter waarbij robuustheid wordt geprefereerd endogeen is beslist. Hoe can modelonzekerheid en een voorkeur voor robuustheid een individuele belegger (zoals een lange-termijn belegger of een pensioenfonds) het maken van beslissingen beïnvloeden. Hoe meet men model onzekerheid in een incomplete finacieele wereld? Hoeveel moeten conservatieve beleggers hun gedrag aanpassen wanneer zij te maken krijgen met model onzekerheid? Welke factoren beslissen de voorkeur voor robuustheid? Is het vermijden van onzekerheid een begrensde parameter? Zo ja, hoe kan dit gemeten worden?

Mijn onderzoek zoekt naar antwoorden op deze vragen terwijl tegelijkertijd geprobeerd wordt om de gaten in de literatuur te vullen met betrekking tot financiële econometry en robuuste asset allocatie. Ik gebruik econometrische theorieën om aan te tonen dat het gedrag van beleggers om onzekerheid te vermijden erg afhankelijk is van hoever de onderliggende informatie onthuld is. Hoe meer gegevens, des te kleiner is de afkeer tegen onzekerheid bij een belegger. Deze eigenschap levert niet alleen een exogene grens aan de afkeer tegen onzekerheid-parameter, maar levert ook potentiële inzichten in verschillende asset pricing puzzels zoals voorkeur voor aandelen van de thuismarkt.

Mijn onderzoek interesse in risicomanagement van pensioenfondsen is gemotiveerd door mijn profesionele ervaring als een junior onderzoeker in Netspar, waar ik actief betrokken was bij discussies over de meest recente pensioen problemen. Een voorbeeld is dat sinds de finaciele crisis in 2008, de meeste pensioenfondsen geconfronteerd zijn met ernstige solvabiliteitsproblemen. De klassieke theorie over beleggingskeuze beargumenteert dat het optimale afdekkingsportefeuille onafhandelijk is van de dekkingsgraad. Echter, empirisch bewijs toont aan dat pensioenfondsen met lage dekkingsgraden eerder geneigd zijn te investeren in aandelen. Het afdekken van een langdurige en stochastis- 
che kasstroom verplichtingen met onvoldoende geld is een uitdaging geworden voor de meeste pensioenfondsen. Dus richt mijn primaire interesse zich op pensioenfondsen met solvabiliteitstekorten.

Mijn onderzoek interesses in het verleden, het heden en de toekomst kunnen worden samengevat in drie categorieën: (1) Beslissingen nemen met model onzekerheid; (2) Afdekken en prijzen in incomplete markten; (3) Risicomanagement van pensioenfondsen. 